\title{
Settlement Quality Mapping Analysis Using Google Earth Imagery and GIS in Sorosutan Subdistrict, Yogyakarta City
}

\author{
Mega Rakhmatika ${ }^{1 *}$, Chafda Larasati $^{1}$, Abraham Cardenas Tristan $^{2}$, Ratih Fitria Putri $^{1}$ \\ ${ }^{1}$ Department of Environmental Geography, Faculty of Geography, Universitas Gadjah Mada, Indonesia \\ ${ }^{2}$ Faculty of Engineering, Autonomous University of San Luis Potosi, San Luis Potosi 78290, Mexico
}

\begin{abstract}
Sorosutan Subdistrict is located in Umbulharjo Subdistrict, Yogyakarta City. The development of Sorosutan Subdistrict is so rapid as indicated by the density of settlements and the complexity of the problems in it. One of these problems is related to settlement conditions. The condition of Sorosutan Subdistrict which has a slum area needs to be investigated on the quality of its settlements through assessment, weighting, and interpretation of Google Earth Imagery. The stage of determining the quality of settlements in this research is interpreting the imagery and determine the scoring of each parameter of settlement quality using GIS software. Based on the analysis of the results of data processing, it was found that the quality of settlements in Sorosutan Subdistrict is partly of medium quality of $54.27 \%$, while good quality is $23.05 \%$ and bad quality is $22.68 \%$. The distribution of good and bad quality settlements dominates the western and southern parts of Sorosutan Subdistrict. The distribution of settlement quality dominates the eastern part of Sorosutan Subdistrict. Hamlets which are decided as slum settlements in these qualities of settlements assessment have bad qualities in hamlet numbers 004 and 015 .
\end{abstract}

\section{Introduction}

The growth of population and development in urban areas is quite rapid. The population growth has resulted in an increasing need for land as a place to live. The development of the urban area is in line with the increase in population so that it raises problems in housing and settlements [1].

The problem of settlements may hinder the existence of good environmental quality. The settlement development that is not organized and not in accordance with the land use triggers the emergence of slum settlements. Based on Law No. 1 of 2011 [2], slum settlements are settlements that are not suitable for habitation due to irregularity of buildings, high building density, and quality of buildings, facilities, infrastructure that do not meet the requirements. Slums that are not handled will further worsen the quality of settlements.

Sorosutan Subdistrict is located in Umbulharjo Subdistrict, Yogyakarta City. Sorosutan Subdistrict has a population of 15,594 people in 2020 with an area of $1.68 \mathrm{~km}^{2}$. The population density of Sorosutan Subdistrict is 9283 people $/ \mathrm{km}^{2}$.

The development of Sorosutan Subdistrict is so rapid as indicated by the density of settlements and the complexity of the problems in it. One of these problems is related to settlement conditions. Based on Yogyakarta Mayor's Decree Number 158 of 2021 [3], several hamlets in Sorosutan Subdistrict are slum settlements. These are located in the neighborhood/hamlet respectively, namely 012/004, 036/015, 040/010, 043/011, 061/016, 062/016, and 065/016.

The condition of Sorosutan Subdistrict which has a slum area needs to be investigated on the quality of its settlements through assessment, weighting, and interpretation of Google Earth Imagery. The assessment, weighting, and interpretation are carried out on settlement areas which include settlement density, settlement layout patterns, road shelter trees, the width of settlement entrances, road surface conditions, and the location of settlements in the surrounding environment. This research can be used as urban spatial planning, especially in Sorosutan Subdistrict.

\section{Methods}

The stage of determining the quality of settlements in this research is interpreting the imagery and determine the scoring of each parameter of settlement quality using GIS software. The first stage is interpreting blocks settlement and non-settlement. Settlement blocks' boundaries are delineated based on hamlets' boundaries and differences in settlement characteristics. The scoring of each parameter in the settlement block is used as a determinant of settlement quality. The data used in this research is Sorosutan Subdistrict Boundary Map, building data, and Google Earth Imagery 2021. The data analysis techniques used in the research are:

\footnotetext{
*Corresponding author: mega.rakhmatika@mail.ugm.ac.id
} 


\subsection{Assessment of The Settlements Quality}

The assessment of the settlements quality uses parameters sourced from the Directorate General of Human Settlements, Department of Public Works (2006). Here are the parameters which can be seen from Google Earth Imagery:

\subsubsection{Settlement Density}

The density of settlements assessed in the research is based on the density of buildings in a settlement block. The density of settlements is measured qualitatively by looking at the uniformity of settlement blocks. The settlement density can be calculated by the formula (1) and the parameters of the settlement density are in Table 1 .

Settlement Density $=\frac{\sum \text { The entire roof area }}{\sum \text { The entire settlement area }} \times 100 \%$

Table 1. Classification and Score of Settlement Density

\begin{tabular}{|l|c|c|}
\hline \multicolumn{1}{|c|}{ Criteria } & Classification & Score \\
\hline $\begin{array}{l}\text { The average settlement } \\
\text { density in a settlement } \\
\text { block is rare (density } \\
<40 \% \text { ) }\end{array}$ & Good & 3 \\
\hline $\begin{array}{l}\text { The average settlement } \\
\text { density in a settlement } \\
\text { block is medium (density } \\
40 \%-60 \%)\end{array}$ & Medium & 2 \\
\hline $\begin{array}{l}\text { The average settlement } \\
\text { density in a settlement } \\
\text { block is dense (density } \\
>60 \% \text { ) }\end{array}$ & Bad & 1 \\
\hline
\end{tabular}

Source: Directorate General of Human Settlements, Department of Public Works (2006).

\subsubsection{Building Layout Pattern}

The building layout pattern is determined by the layout regularity and the building size. Buildings that have the same relative size and follow a certain pattern are grouped in the same settlement block unit. The formula and table for the classification of building regularity patterns can be seen below.

Building Layout Pattern $=\frac{\sum \text { Regular buildings }}{\sum \text { Buildings }} x 100 \%$

Table 2. Classification and Score of Building Layout Patterns

\begin{tabular}{|l|c|c|}
\hline \multicolumn{1}{|c|}{ Criteria } & Classification & Score \\
\hline $\begin{array}{l}>50 \% \text { of the } \\
\text { existing buildings } \\
\text { in a settlement } \\
\text { block are orderly } \\
\text { arranged }\end{array}$ & Good & 3 \\
\hline
\end{tabular}

\begin{tabular}{|l|c|c|}
\hline $\begin{array}{l}25 \%-50 \% \text { of the } \\
\text { existing buildings } \\
\text { in a settlement } \\
\text { block are orderly } \\
\text { arranged }\end{array}$ & Medium & 2 \\
\hline $\begin{array}{l}<25 \% \text { of the } \\
\text { existing buildings } \\
\text { in a settlement } \\
\text { block are orderly } \\
\text { arranged }\end{array}$ & Bad & 1 \\
\hline
\end{tabular}

Source: Directorate General of Human Settlements, Department of Public Works (2006).

\subsubsection{Trees of Settlements' Shelter}

Trees around settlements are used to shelter the entrance to settlement block and reduce pollution caused by vehicles. The classification of shelter trees in each settlement block is determined as shown in the Table 3.

Table 3. Classification and Score of Settlements' Shelter Trees

\begin{tabular}{|l|c|c|}
\hline \multicolumn{1}{|c|}{ Criteria } & Classification & Score \\
\hline $\begin{array}{l}\text { If the settlement block } \\
\text { has a shelter tree }\end{array}$ & Good & 2 \\
\hline $\begin{array}{l}\text { If the settlement block } \\
\text { does not have a shelter } \\
\text { tree }\end{array}$ & Bad & 1 \\
\hline
\end{tabular}

Source: Directorate General of Human Settlements, Department of Public Works (2006).

\subsubsection{The Width of Settlements' Road}

The width of the road referred to in this research is the average width of the road which connects the local road with the main road in a settlement block. The following table of criteria to determine the quality of the road width of a settlement block.

Table 4. Classification and Score of Settlements' Road Width

\begin{tabular}{|l|c|c|}
\hline \multicolumn{1}{|c|}{ Criteria } & Classification & Score \\
\hline $\begin{array}{l}\text { Average road width } \\
>6 \mathrm{~m}\end{array}$ & Good & 3 \\
\hline $\begin{array}{l}\text { Average road width } \\
\text { between 4-6m }\end{array}$ & Medium & 2 \\
\hline $\begin{array}{l}\text { Average road width } \\
<4 \mathrm{~m}\end{array}$ & $\mathrm{Bad}$ & 1 \\
\hline
\end{tabular}

Source: Directorate General of Human Settlements, Department of Public Works (2006).

\subsubsection{Road Surface Condition}

The condition of the road surface can be determined from the type of paving material, which is based on the percentage of the asphalt hardened road condition for the entire road. Assessment of road surface condition through Google Earth Imagery is carried out by paying attention to the hue of the object. 
Calculation of road surface condition in each settlement block is calculated using the formula (3) The classification used for assessing the road surface condition is listed in the Table 5.

Road Surface Condition $=\frac{\sum \text { Paved road length }}{\sum \text { Entire road length }} \times 100 \%$

Table 5. Classification and Score of Road Surface Condition

\begin{tabular}{|l|c|c|}
\hline \multicolumn{1}{|c|}{ Criteria } & Classification & Score \\
\hline $\begin{array}{l}>50 \% \text { of the length of } \\
\text { the existing road in the } \\
\text { settlement block is } \\
\text { hardened with asphalt. }\end{array}$ & Good & 3 \\
\hline $\begin{array}{l}25 \%-50 \% \text { of the length } \\
\text { of the existing road in } \\
\text { the settlement block is } \\
\text { hardened with asphalt. }\end{array}$ & Medium & 2 \\
\hline $\begin{array}{l}<25 \% \text { of the length of } \\
\text { the existing road in the } \\
\text { settlement block is } \\
\text { hardened with asphalt. }\end{array}$ & Bad & 1 \\
\hline
\end{tabular}

Source: Directorate General of Human Settlements, Department of Public Works (2006).

\subsubsection{The Location of Settlement}

The assessment of the settlement location parameter is based on the proximity of the settlement to the source of pollution. The following table of criteria to determine the quality of location of a settlement:

Table 6. Classification and Score of Settlement Location

\begin{tabular}{|l|c|c|}
\hline \multicolumn{1}{|c|}{ Criteria } & Classification & Score \\
\hline $\begin{array}{l}\text { If the location of the } \\
\text { settlement is far from the } \\
\text { source of pollution } \\
\text { activities (industry, } \\
\text { factory, and market) }\end{array}$ & Good & 3 \\
\hline $\begin{array}{l}\text { If the location of the } \\
\text { settlement is not directly } \\
\text { affected by the pollution } \\
\text { source activities } \\
\text { (industry, factory, and } \\
\text { market) }\end{array}$ & Medium & 2 \\
\hline $\begin{array}{l}\text { If the location of the } \\
\text { settlement is close to } \\
\text { sources of air and noise } \\
\text { pollution (industry, } \\
\text { factory, and market) }\end{array}$ & Bad & 1 \\
\hline
\end{tabular}

Source: Directorate General of Human Settlements, Department of Public Works (2006).

\subsection{Distribution of Settlement Quality Classes in Sorosutan Subdistrict}

The assessment of the settlement quality class is based on the total score. The total score is obtained from the sum and multiplication of the score of each determining parameter with a weighing factor. Calculation of the total score in each settlement block is calculated using the formula (4).

Total Score $=(A \times 3)+(B \times 1)+(C \times 2)+(D \times 3)+(E \times 2)+(F \times 2)$

Information:

A: Score of Settlement Density

B: Score of Settlement Layout

C: Score of The Settlements' Shelter Tree

D: Score of The Road Width

E: Score of The Road Surface Condition

F: Score of Settlement Location

Source: Directorate General of Human Settlements, Department of Public Works (2006).

After determining the highest and lowest of the total score, then determine the class interval (range) with the formula (5).

Class Interval $=\frac{(\text { Highest score-Lowest score })}{\text { Number of classes }}$

Source: Directorate General of Human Settlements, Department of Public Works (2006).

\section{Results and Discussions}

The quality of settlements of an area is determined by several parameters. These parameters can be interpreted using Google Earth Imagery, namely population density parameters, settlement layout parameters, road width parameters, road conditions parameters, shelter tree parameters, and settlement location parameters.

\subsection{Settlements Quality}

\subsubsection{Settlement Density Parameters}

Determination of settlement density can be seen from the imagery by looking at the presence of buildings that are close to each other. Density assessment is done by finding the roof area which is then divided by the area of the settlement block. According to the diagram (Fig. 1), it is found that Sorosutan Subdistrict is dominated by settlement blocks with medium density with an area of 94,8 ha or $78.93 \%$ of the total area of settlements in Sorosutan Subdistrict. The density of settlements in the good category is still a small part of the area, which means that buildings with low density that make space to move freely and wide road access are still rare in this Subdistrict. The density of these settlements resulted in poor air circulation due to the lack of trees around the settlements. The density level is either only an area of 11,1 ha or about $9.27 \%$ of the total administrative area of Sorosutan Subdistrict. 


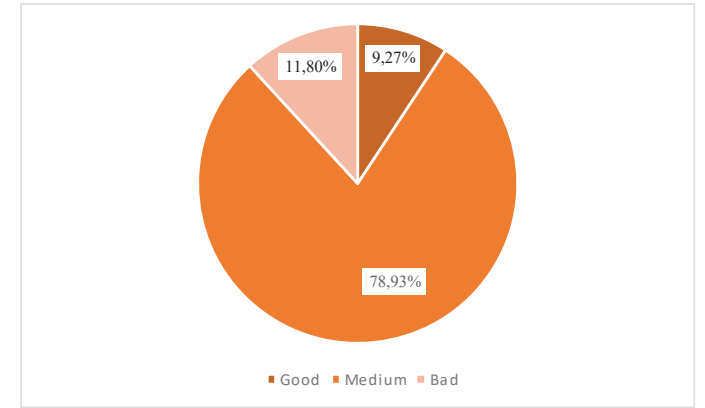

Fig. 1. Percentage of Block Quality Area on Settlement Density Parameters

\subsubsection{Settlement Layout Pattern}

The settlement layout pattern is assessed based on the regularity between buildings in the settlement block. The regularity of the building is interpreted based on the pattern and shape of the building. The settlement layout pattern is assessed as good, medium, and bad.

Sorosutan Subdistrict mostly has a bad settlement layout pattern. The total settlements area of Sorosutan Subdistrict is dominated by bad settlement layout patterns covering an area of $64.84 \%$ (Figure 3.1.1). Meanwhile, the layout pattern of good settlements has a score of $18.45 \%$ (Fig. 2) and medium has a score of $16.68 \%$ (Fig. 2). Neat and well-organized buildings are influenced by the factor of vacant [4]. The settlement pattern of Sorosutan Subdistrict which is dominated by bad conditions can be caused by the decrease of vacant land.

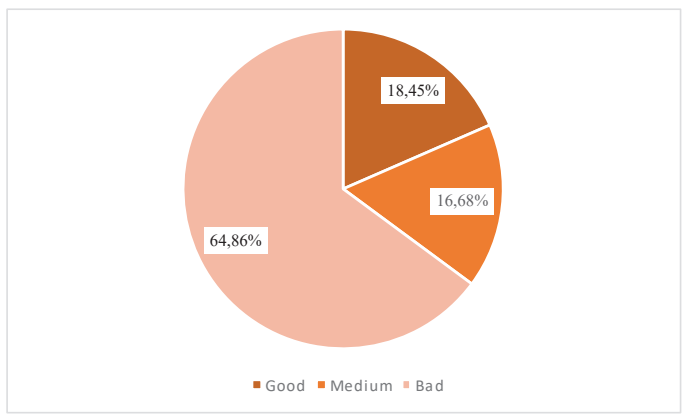

Fig. 2. Percentage of Block Quality Area on Settlement Layout Pattern Parameters

\subsubsection{Shelter Tree Parameters}

Shelter trees have an influence on the comfort level, settlement blocks with lots of trees have less heat. In addition, shelter trees are also used to reduce air pollution from vehicles. With Google Earth Imagery, the shelter tree measurement is seen from a green hue which looks clustered due to the thick leaves. Shelter tree parameters are only divided into two, namely good and bad.

Based on the diagram (Fig. 3.) shelter trees with good class dominate the settlements in Sorosutan Subdistrict, which are 106,6 ha with a percentage of
$88.78 \%$. However, some areas are still classified as bad with an area of 13,4 ha and a percentage of $11.22 \%$ of the total area of settlements in Sorosutan Subdistrict.

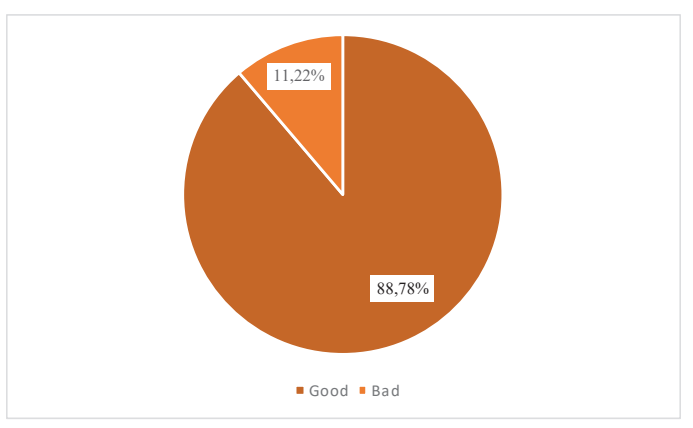

Fig. 3. Percentage of Block Quality Area on Shelter Tree Parameters

\subsubsection{The Width of Settlement Entrance}

The width of the entrance to the settlement indicates the ease of mobility and accessibility, especially for transportation. The width of this road is calculated based on the width of the entrance to the settlement block from the main road. The width of the entrance to settlements with a score of more than 6 meters is categorized as good, while the bad category has a width of fewer than 4 meters. The width of this road is known based on imagery interpretation and measurements.

The total block area of $38.87 \%$ (Fig. 4) Sorosutan Subdistrict has a good quality road width. This shows that many roads leading to settlements can be passed by 2-3 cars freely, this means that it is easy for transportation to pass. Settlement blocks with a medium quality road width is an area of $36.91 \%$ (Fig. 4) and bad quality is an area of $24.21 \%$ (Fig. 4).

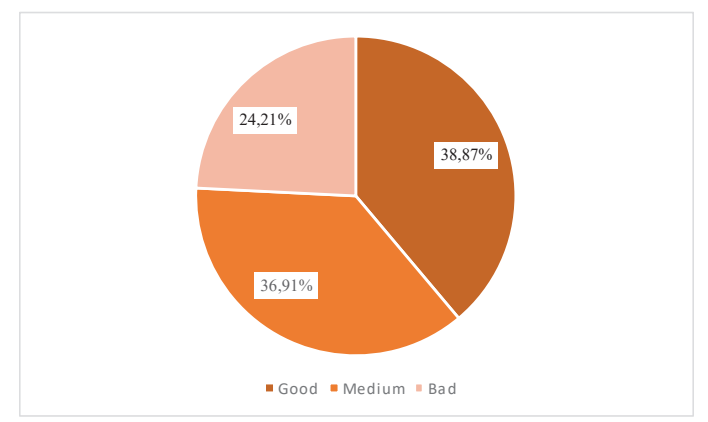

Fig. 4. Percentage of Block Quality Area on The Width of Settlement Entrance Parameters

\subsubsection{Road Surface Condition Parameters}

The condition of the road surface is categorized as good if the road is made of asphalt. Roads that are classified as asphalt can make it easier for road users to drive and feel comfortable. This asphalt road is often found in urban areas. Parameters of road surface conditions are related to the width of the road. A wide road can be assumed to have been paved with asphalt. 
Sorosutan Subdistrict has good road surface conditions in all settlements. This shows that there are no settlement blocks less than $50 \%$ whose roads are still in the form of soil. The condition of the road in Sorosutan Subdistrict has been $100 \%$ completely paved with asphalt (Fig. 5). The condition of the road which is paved with asphalt shows that the quality of the settlement is good because it facilitates accessibility.

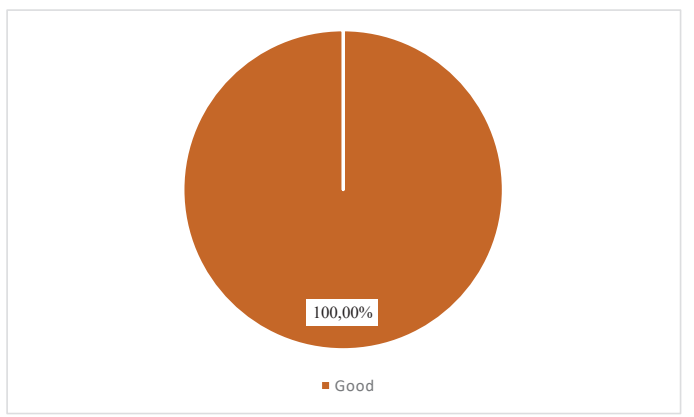

Fig. 5. Percentage of Block Quality Area on Road Surface Condition Parameters

\subsubsection{Location}

Settlement location parameters are used in determining the quality of settlements on the basis of pollution. Pollution in settlements comes from factories, industries, and markets. The location of settlements against pollution sources is classified into good, medium, and bad classes. The location of settlements that are closer to the source of pollution, the quality of the location is getting worse.

Sorosutan Subdistrict is a part of the center of Yogyakarta. The city that acts as the center of these activities certainly has a variety of industries, factories, and markets as sources of settlement pollution. This condition can be seen from the area of the Sorosutan Subdistrict which has poor quality in location parameters. This poor quality dominates the total settlement blocks area in the Subdistrict by $71.54 \%$ (Fig. 6). Medium quality has a percentage of $16.02 \%$ (Fig. 6) and good quality has a percentage of $12.41 \%$ (Fig. 6) of the total settlement block area of Sorosutan Subdistrict.

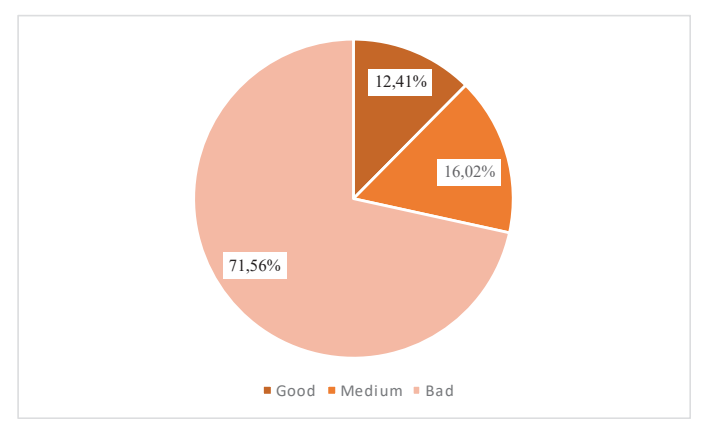

Fig. 6. Percentage of Block Quality Area on Location Parameters

\subsection{Distribution of Settlement Quality in Sorosutan Subdistrict, Umbulharjo District, Yogyakarta City}

Assessment of settlement quality is obtained from six parameters determining the quality of settlements through imagery interpretation. These parameters are settlement density, building layout, road width, road surface conditions, settlement locations, and shelter trees. The parameter is then calculated the total score according to the weight of each parameter to obtain an assessment of the quality of settlements in an area. After knowing the total score in each settlement block, a classification of settlement quality classes is produced. The results of the classification of each class can be seen in Fig. 7.

The result of the area of each settlement class calculation shows that Sorosutan Subdistrict is dominated by the quality of medium settlements, then good and the last is bad. According to the calculation, the medium settlement quality class has an area of 65,19 ha or $54.72 \%$ of the total area of settlements in Sorosutan Subdistrict (Fig. 7). Settlement blocks with medium quality spread in Sorosutan Subdistrict. As shown in the (Fig. 8) the green hue is dominating Sorosutan Subdistrict.

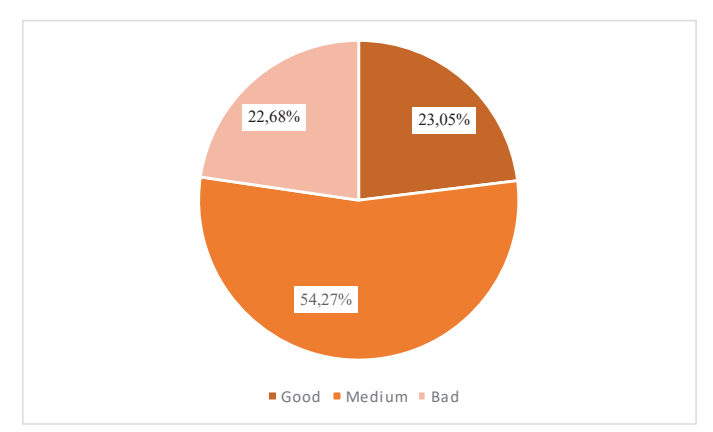

Fig. 7. Percentage of Block Quality Area

Based on the Fig. 8, Sorosutan Subdistrict has 15 settlement blocks with good grades. The settlement block covers an area of 27,6 ha or $23.05 \%$ of the total area of settlements in Sorosutan Subdistrict. Settlement blocks that are classified as good are blocks 4, 10, 12, $13,15,16,18,20,22,23,24,26,29,30,34$. The criteria for good settlement quality are low settlement density, there are protective trees, road width $>6 \mathrm{~m}$, regular settlement pattern, the location of the settlement is far from pollution sources, has a road surface that has been paved with asphalt, and has good road access. Mediumclass settlement blocks in Sorosutan Subdistrict are spread throughout the region and are dominated by the eastern part of Sorosutan Subdistrict.

The blocks are blocks 5, 6, 7, 8, 9, 14, 19, 28, 32, 35, $37,40,41,42$. The medium class has criteria for the quality of settlements being not too dense, there are shade trees, road width $4-6 \mathrm{~m}$, the settlement pattern is quite regular, the location of the settlement is far from pollution sources, has an asphalt surface, and good road access. The low-class settlement block has an area of 
27,2 ha or $22.68 \%$ of the total area of settlements in Sorosutan Subdistrict. The settlement blocks are 1, 2, 3, $11,17,21,25,27,31,33,36,38,39$. The distribution of bad settlement quality dominates the western and southern parts of Sorosutan Subdistrict. These bad quality settlement blocks are located close to factories, industries, and markets. Other criteria for settlement blocks include high density, irregular settlement patterns, no protected trees, and difficult road access. Indiscriminate development can cause some parameters that determine the quality of settlements to be bad, such as the width of the entrance being small due to too tight construction. Hamlets designated as slums in the assessment of the quality of these settlements have low quality in hamlet number 004 and 015.

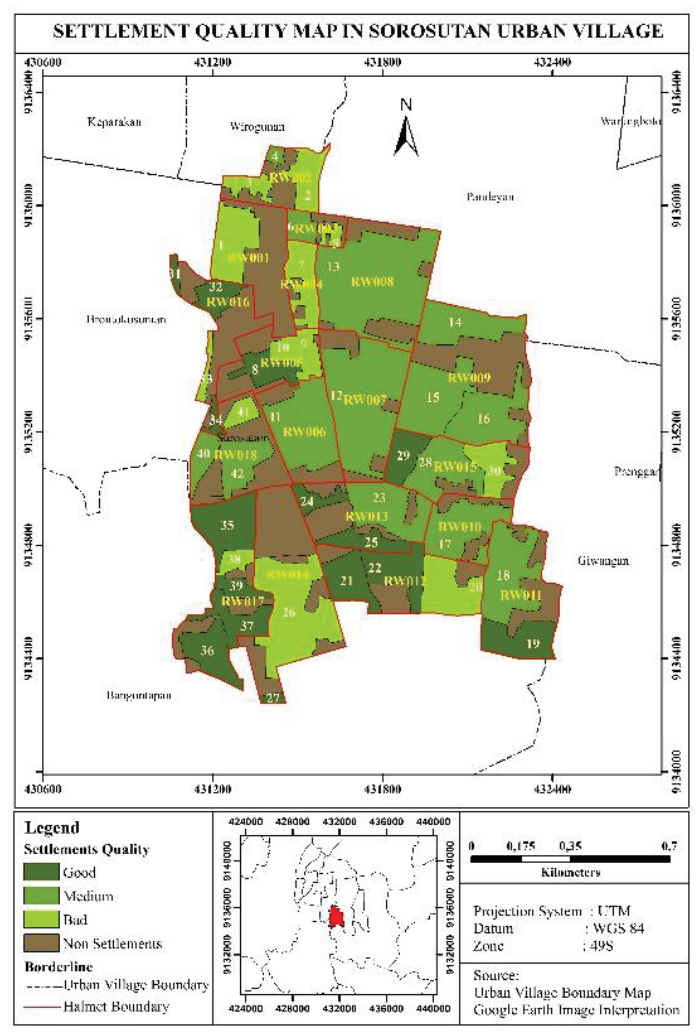

Fig. 8. Settlements Quality Map in Sorosutan Hamlet Subdistrict in each Hamlet

\section{Conclusions}

The quality of settlements in Sorosutan Subdistrict is determined by the density of settlements, settlement layout patterns, road shelter trees, the width of the settlement entrance, the condition of the settlement roads, and the location interpreted through Google Earth Imagery. The quality of settlements in Sorosutan Subdistrict is partly of medium quality of $54.27 \%$, while good quality is $23.05 \%$ and bad quality is $22.68 \%$. The distribution of good and bad quality settlements dominates the western and southern parts of Sorosutan Subdistrict. The distribution of settlement quality dominates the eastern part of Sorosutan Subdistrict.
Hamlets which are decided as slum settlements in these qualities of settlements assessment have bad qualities in hamlet numbers 004 and 015 .

\section{References}

1. W. T. Prasetyo and S. Rahayu, Tek. Perenc. Wil. Kota 2, 293 (2013)

2. Undang-undang Nomor 1 Tahun 2011, Perumahan Dan Kawasan Permukiman (Indonesia, 2011), pp. 1-136

3. Keputusan Walikota Yogyakarta Nomor 158 Tahun 2021, Penetapan Lokasi Perumahan Kumuh Dan Permukiman Kumuh (Yogyakarta, 2021), pp. 1-19

4. M. Farizki and W. Anurogo, Maj. Geogr. Indones. 31, 39 (2017) 